\title{
Evaluation of Certain Chemical Fungicides for Controlling the White Garden Snail, Theba pisana (Muller)
}

\author{
Mesbah, H. A. A. , A. K. Mourad*, M. M. El-Shazly", E. H. Eshra** and Emtiaz E. \\ E. Ghoneim ${ }^{\star *}$ \\ * Faculty of Agric. (Saba Basha), Alex. Univ. Egypt. \\ **Plant Protection Research Institute, Agric. Res. Center, Egypt.
}

\begin{abstract}
The present research was carried out during the season of 2014 for controlling the white garden snail, Theba pisana (Muller) under laboratory conditions by using some chemical fungicides (Copper sulfate $50 \%$, Copper hydroxide $53.8 \%$ and Benalaxyl) with three concentrations $(0.5,0.25$ and $0.125 \%)$ for each insecticides as spraying lettuce leaves and baits. The results showed that, in all concentrations, the mortality rates increased by the time and most mortality achieved over seven days post fungicides treatments, for the white garden snail, Theba pisana (Muller) by concentrations of $0.5 \%, 0.25 \%$ and $0.125 \%$, in respectively for both treated spraying lettuce leaves and baits.

Spraying lettuce leaves of copper sulfate $50 \%$ were achieved mortality percentages 64,57 and 38 for concentrations $(0.5,0.25$ and $0.125 \%)$, respectively while baits were achieved mortality percentages 52, 48 and 24 for the same concentrations after 7 days, in this respect. The corresponding $\mathrm{LT}_{50}$ (day) values were 5.21, 6.08 and 9.27 for spraying lettuce leaves and 7.03, 6.96 and 9.70 for baits at tested concentrations of $0.5 \%, 0.25 \%$ and $0.125 \%$. Copper hydroxide $53.8 \%$ achieved mortality percentages 48.32 and 17 for the same concentrations in spraying lettuce leaves but in baits achieved 28, 21 and 13 for the same concentrations after 7 days, respectively, corresponding to $\mathrm{LT}_{50}$ (day) values were $8.46,8.59$ and 10.27 for spraying lettuce leaves and 10.27, 9.31 and 11.32 for baits at its tested concentrations of $0.5 \%, 0.25 \%$ and $0.125 \%$, in respect. Also. benalaxyl achieved mortality percentages 62,34 and 16 for the same concentrations in spraying lettuce leaves but in baits the mortalities achieved 54,30 and 11 for the same concentrations after 7 days, in respect, corresponding to $\mathrm{LT}_{50}$ (day) values of $6.24,9.56$ and 22.20 for spraying lettuce leaves while for baits the values were $7.04,8.56$ and 15.21 at its tested concentrations.
\end{abstract}

Key words: Fungicides, Toxicity, White garden snail and control of land snails.

\section{INTRODUCTION}

The terrestrial gastropods are economic pests attacking several types of plants, vegetables, horticultural plants, field crops and other plants. These animals' pests have chewing mouth parts and attack the plant parts (Godan, 1983 and Ghoneim,2006)

In Egypt, the land mollusca species are serious economic land pests attacking plants especially the northen coastal areas. This damage includes leaves, flower, fruits and stems of the agricultural plantations (Ryder and Bowen, 1977). Recently, these pests appeared to cause wide spread damage in field and orchards in many Governorates of Egypt. Moreover, the land snails require moisture conditions and they feed at night when the enough requirements of the moisture and temperature are suitable particularly during winter and spring seasons (El-Okda, 1980; Eshra, 2004; Ghoneim, 2006 and Eshra, 2013).

According to the damage caused by the land snails as well as their effect to decrease the agricultural yield quality, the control of these pests attracted the attention of many investigators. The investigators applied different methods for the 
land snails' control. These methods involved agricultural practices, the application of inorganic and organic pesticides, fungicides and others (El-Okda, 1980; ElOkda et al. 1990; El-Shahaat et al., 1995; Moran et al., 2004; Eshra, 2004; ElShahaat et al., 2005; Eshra, 2013 and Eshra et al., 2015)

The present investigation aims to study the molluscicidal activity of some fungicides on the white garden snail, Theba pisana (Muller) under laboratory conditions.

\section{MATERIALS AND METHODS}

\section{Snail collection}

Adult white garden snail, Theba pisana (Muller) order: Pulmonata, family: Helicideae were collected during the spring season of 2014 from some agricultural regions in Alexandria and El-Beheira Governorates and transferred into glass $(60 \times$ $40 \times 40)$ to the laboratory for testing the fungicides efficiently at conditions of $25 \pm$ $2 \mathrm{C}$ and $65 \pm 5 \% \mathrm{RH}$. The aquaria were tightly covered with cloth netting and the snails were daily fed on lettuce leaves for one week for acclimatization under laboratory condition priestly experiments snails were staved for $48 \mathrm{hrs}$ before assays.

\section{Fungicides used}

Copper sulfate 50\% (Cupral 50\%® WP), Copper hydroxide 53.8\% (Kocide 2000. 53.8\%) and Benalaxyl (Galben copper®) with three concentrations $(0.5,0.25$ and $0.125 \%$ ). These fungicides sprayed on the land snails with the same concentrations $(0.5$. 0.25 and $0.125 \%)$ and the obtained baits was colored using an aqueous solutions of these fungicides. The chosen substances were wheat bran (fine fraction) and fine fraction of sawdust in a mixture of $(1: 1 \mathrm{w} / \mathrm{w})$. The obtained baits was coloured using an aqueous solution of a blue paint substance $(0.5 \%)$ as colour attractant for gastropods (El-Okda et al., 1989).

\section{Laboratory molluscicidal activity of certain fungicides}

The laboratory work was carried out in sealed plastic vessels $(22 \times 15 \times 10 \mathrm{~cm})$ with five replicates, each contain 10 snail individuals. The tested of treatments were 18 (9 for spraying lettuce leaves and 9 for baits) plus untreated check as control. The $1^{\text {st }}$ treatment was carried out to evaluate the efficiency of Copper sulfate $50 \%$ with 3 concentrations $0.5,0.25$ and $0.125 \%$ using the technique of lettuce leaves which have been sprayed with this fungicide. The $2^{\text {nd }}$ treatment included Copper hydroxide $53.8 \%$ with the same concentrations $0.5,0.25$ and $0.125 \%$ and using the same technique of lettuce leaves which have been sprayed with this fungicide and baits. Also, the $3^{\text {rd }}$ treatment included Benalaxyl with the same concentrations $0.5,0.25$ and $0.125 \%$ and using the same technique of lettuce leaves which have been sprayed with this fungicides and baits.

Moreover, in the previously carried out tests, the killed snails' individuals were removed daily and the accumulative mortality effects were recorded after 1, 3, 5 and 7 days after treatments. The mortality percentages were corrected using Abbott's 
formula (Abbott, 1925) and then exposed to the angular transformation. Also, the lethal time $\left(\mathrm{LT}_{50}\right)$ for $50 \%$ mortality was estimated.

\section{RESULTS AND DISCUSSIONS}

The efficiency of some copper fungicides against the white garden snail, Theba pisana (Muller) was determined by feeding snails on sprayed lettuce leaves under laboratory conditions. The obtained results are shown in Table (1) and Fig (1), the calculated mortality values percentage as commutative effect up to 7 days after treatment, gradually increased with time. The deduced mortality values comprised 64,57 and $38 \%$ after 7 days from feeding snails on the treated leaves with copper sulfate $50 \%$ fungicide at the concentrations of $0.5 \%, 0.25 \%$ and $0.125 \%$, respectively. The corresponding $\mathrm{LT}_{50}$ (day) values were 5.21, 6.08 and 9.27 . The estimated \% mortality values for the lower efficient copper hydroxide $53.8 \%$ amount to 48,32 and $17 \%$, respectively, corresponding to $\mathrm{LT}_{50}$ (day) values of $8.46,8.59$ and 10.27 at its tested concentrations of $0.5 \%, 0.25 \%$ and $0.125 \%$, in respect.

While the tested concentrations of benalaxyl fungicide $(0.5 \%, 0.25 \%$ and $0.125 \%$ ) gave mortality values of 62,34 and $16 \%$ corresponding to the calculated $L_{50}$ (day) values of $6.24,9.56$ and 22.20 , in respect.

Table (1). Toxicity of some fungicides sprayed against the white garden snail, Theba pisana (Muller) under laboratory conditions.

\begin{tabular}{|c|c|c|c|c|c|c|}
\hline \multirow{2}{*}{\multicolumn{2}{|c|}{$\begin{array}{c}\text { Concentrations } \\
\%\end{array}$}} & \multicolumn{4}{|c|}{$\%$ Mortality as cumulative effect after } & \multirow{2}{*}{$\mathrm{LT}_{50}$ (day) } \\
\hline & & $0-1$ day & 0-3 day & 0-5 day & 0-7 day & \\
\hline \multirow{3}{*}{ 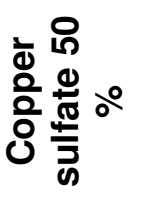 } & 0.5 & 8.0 & 34.0 & 42.0 & 64.0 & $5.21(4.39-6.24)$ \\
\hline & 0.25 & 0.0 & 27.0 & 35.0 & 57.0 & $6.08(5.28-7.02)$ \\
\hline & 0.125 & 0.0 & 18.0 & 24.0 & 38.0 & $9.27(7.12-12.21)$ \\
\hline \multirow{3}{*}{ 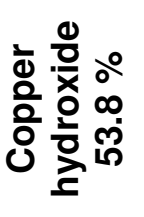 } & 0.5 & 2.0 & 3.0 & 18.0 & 48.0 & $8.46(6.92-10.41)$ \\
\hline & 0.25 & 0.0 & 1.0 & 6.0 & 32.0 & $8.59(7.34-10.06)$ \\
\hline & 0.125 & 0.0 & 0.0 & 4.0 & 17.0 & $10.27(7.75-13.65)$ \\
\hline \multirow{3}{*}{ 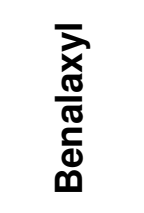 } & 0.5 & 0.0 & 12.0 & 28.0 & 62.0 & $6.24(5.63-6.92)$ \\
\hline & 0.25 & 0.0 & 11.0 & 25.0 & 34.0 & $9.56(7.35-12.56)$ \\
\hline & 0.125 & 0.0 & 7.0 & 12.0 & 16.0 & $22.20(10.20-51.39)$ \\
\hline
\end{tabular}




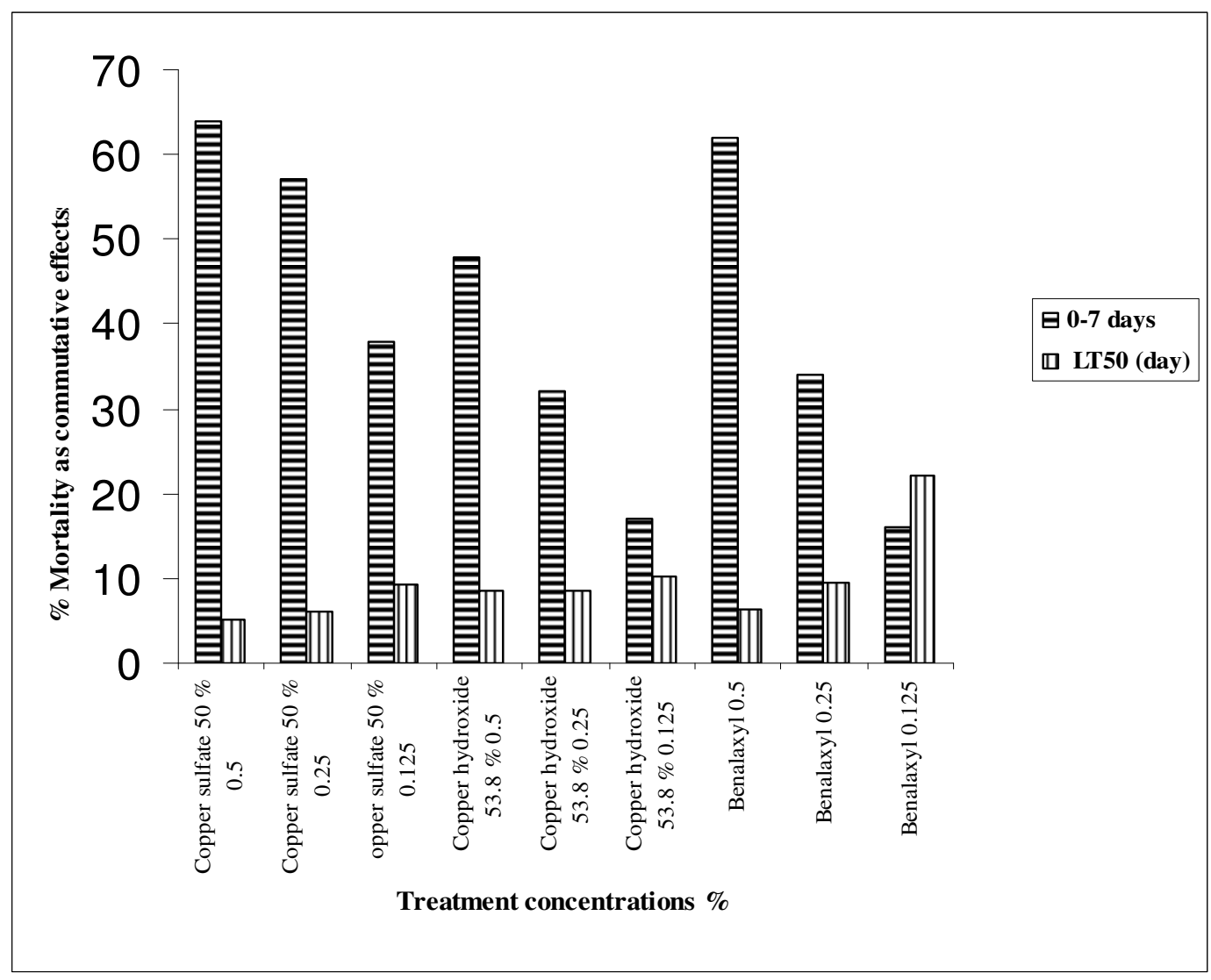

Fig. (1). Toxicity of some fungicides sprayed against the white garden snail, Theba pisana (Muller) under laboratory conditions.

Also, the results in Table (2) and illustrated in Fig. (2). showed that. the toxicity of prepared poison baits of certain tested fungicides against the white garden snail, Theba pisana (Muller). The commutative \% mortalities values amounted to $52,48,24,28,21,13,54,30$ and 11 after 7 days of feeding on the prepared baits of copper sulfate $50 \%$, copper hydroxide $53.8 \%$ and benalaxyl, respectively. These results corresponded to $\mathrm{LT}_{50}$ (day) values of $7.03,6.96,9.70$, $10.27,9.31,11.32,7.04,8.86$ and 15.21 for copper sulfate $50 \%$ in concentrate (0.5, 0.25 and 0.125$)$, copper hydroxide $53.8 \%$ in concentrate $(0.5,0.25$ and $0.125 \%)$ and benalaxyl in concentrate of $(0.5,0.25$ and $0.125 \%)$, in respect.

From these findings it could be seen that the highest toxicity effect was revealed for copper sulfate $50 \%$ bait $(0.25 \%$ and $0.5 \%)$ and benalaxyl bait $(0.25 \%$ and $0.5 \%)$ followed by copper hydroxide $53.8 \%$ baits $(0.25 \%)$, copper sulfate $50 \%$ bait $(0.25 \%)$, copper hydroxide $53.8 \%$ baits $(0.5 \%)$, copper hydroxide $53.8 \%$ baits $(0.125 \%)$ and benalaxyl baits $(0.125 \%)$, while the remaining fungicides gave less efficacy.

Remarkably, from the above mentioned results it could be revealed that the applications of inorganic salts (particularly copper compounds) either by foliar 
sprays of lettuce leaves or baits were effective against the white garden snail, Theba pisana (Muller).

Our results agree to a great extent with those obtained by El-Wakil and Mesbah (1995), those evaluated the low concentrations of copper sulfate solutions $(0.25,0.5,1.0$ and $1.5 \mathrm{~g} /$ /iter water $)$ for three times for each tested concentration on the infestation rate of the white garden snail, Theba pisana (Muller) snails in Vicia faba L. Results showed a significant decrease in the numbers of counted snails among different treatments. The concentration of 1.0 and $1.5 \mathrm{~g} /$ /iter water exhibited the highest effects in decreasing the same percentage number of snails at the end of experiment by $96.56 \%$, besides the determined significant differences in the productivity of different treated plants. In particular the concentration of $1.5 \mathrm{~g} / \mathrm{liter}$ water copper sulfate solution gave the highest productivity of plants and decrease in the number of occurring snails. Also, Speiser and Kistler (2002) found that pellets containg $1.0 \%$ iron phosphate reduced leaf loss of lettuce, increased the number of marketable lettuce heads and reduced numbers of the slug, Arion lustanicus.

Moran et al. (2004) found that copper hydroxide gave promising efficiency against land gastropoda. Also, copper compounds such as oxides and salts are effective repellents (Godan, 1983). Copper complex compounds containing mainly copper silicates, which has been registered in Australia for management of land snails, has been demonstrated to have significant repellency (Davis et al.. 1996). Baits of kocide 2000, copper hydroxide (5\% cu) and acrobat copper (5\% cu) gave $37 \%$ mortality after 5 days of application in apple orchard (El-Shahaat et al., 2009).

Results of Abo El-Ftooh (2012) showed that the percentages of mortalities of the snail, $M$. cantiana depended on concentration and exposure time. Higher concentration of the tested pesticides gave the higher percentages of the mortality. Generally, the pesticides, selecron $\AA 72 \%$, cidial $\AA 50 \%$ and copper sulfate $\AA 1 \%$ exhibited the higher mortality \%, while pesticides of galben "c" ${ }^{\circledR} 46 \%$ recorded the lower mortality \%. Also, the results showed that the application of selecron® $72 \%$ and cidialß $50 \%$ were important to control land snail, and enhancing yield.

Eshra (2014) reported that copper hydroxide was the most toxic compound against $E$. vermicalata followed by methomyl and urea fertilizer after $72 \mathrm{hrs}$ of evaluation were $\mathrm{LC}_{50}$ values were $3.31 \%, 3.75 \%$ and $40.88 \%$, respectively. 
Table (2). Toxicity of some fungicides baits against the white garden snail, Theba pisana (Muller) under laboratory conditions.

\begin{tabular}{|c|c|c|c|c|c|c|}
\hline \multirow{2}{*}{\multicolumn{2}{|c|}{$\begin{array}{c}\text { Concentrations } \\
\%\end{array}$}} & \multicolumn{4}{|c|}{$\%$ Mortality as cumulative effect after* } & \multirow{2}{*}{$\mathrm{LT}_{50}$ (day) } \\
\hline & & 0-1 day & $0-3$ day & $0-5$ day & 0-7 day & \\
\hline \multirow{3}{*}{ 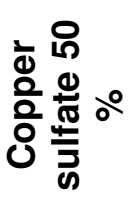 } & 0.5 & 3.0 & 6.0 & 38.0 & 52.0 & $7.03(5.97-8.31)$ \\
\hline & 0.25 & 0.0 & 0.0 & 22.0 & 48.0 & $6.96(6.41-7.57)$ \\
\hline & 0.125 & 0.0 & 0.0 & 18.0 & 24.0 & $9.70(7.65-12.34)$ \\
\hline \multirow{3}{*}{ 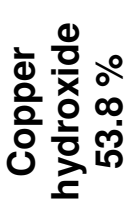 } & 0.5 & 0.0 & 3.0 & 12.0 & 28.0 & $10.27(7.79-13.63)$ \\
\hline & 0.25 & 0.0 & 0.0 & 4.0 & 21.0 & $9.31(7.58-11.45)$ \\
\hline & 0.125 & 0.0 & 0.0 & 3.0 & 13.0 & $11.32(7.75-16.61)$ \\
\hline \multirow{3}{*}{ 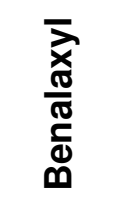 } & 0.5 & 0.0 & 6.0 & 17.0 & 54.0 & $7.04(6.31-7.86)$ \\
\hline & 0.25 & 0.0 & 1.0 & 21.0 & 30.0 & $8.86(7.30-10.80)$ \\
\hline & 0.125 & 0.0 & 0.0 & 8.0 & 11.0 & $15.21(8.31-28.30)$ \\
\hline
\end{tabular}

${ }^{*}$ Each value is corrected by Abbott's Formula and is an average of 5 replicates (each contain 10 snail individuals).

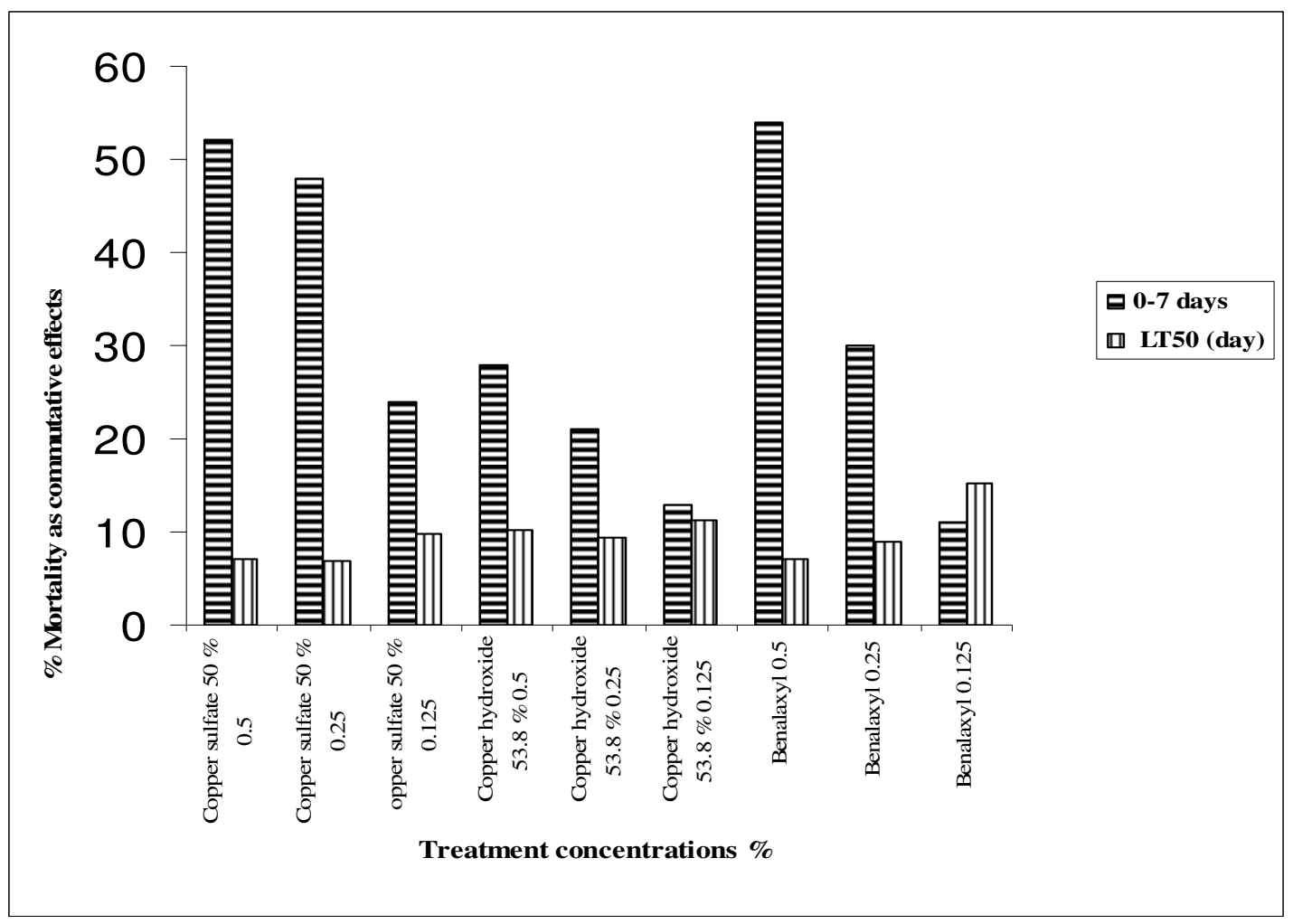

Fig. (2). Toxicity of some fungicides baits against the white garden snail, Theba pisana (Muller) under laboratory conditions. 
J. Adv. Agric. Res. (Fac. Agric. Saba Basha)

\section{REFERENCES}

Abbott, W. S. (1925). A method of computing the effectiveness of an insecticide. J. Econ. Entomol., 18(2): 265-267.

Abo El-Ftooh, A. A (2012). Survey. population densities and control of land snail species infesting sugarbeet fields at West Nubaryia region. J. Adv. Agric. Res. fac. Agric .Saba .Basha, 17(4): 858-879.

Davis, P. R., J. J. Van, M. A. Widmer and T. J. Craven (1996). Assessment of the molluscicidal activity of copper complex compound. BCPC symposium proceedings No.66.slug \& snail pests in Agriculture.University of Kent.Canterberg.24-26September, pp. 53-62.

El-Okda, M. M. K. (1980). Land snails of economic importance on vegetable crop at Alexandria and Neighboring regions. Agric. Res. Rev. Egypt, 58: 79-86.

El-Okda, M. M. K., M. M. Emara and M. A. Selim (1989). The response of the harmful and useful terrestrial mousca towards several toxicants: Efficacy of six toxicant under laboratory conditions. Alex. Sci. Exch., 10(3): 375-385.

El-Okda, M. M. K., M. S. El-Shahaat, M. M. Emara and H. A. Hanfei (1990). Cultural control of terrestrial mollusca. 2-Hand collction of pest snails. J. Pest control and Environ. Sci., 2: 243-251.

El-Shahaat, M. S., E. H. Eshra and Y. Abo-Bakr (2005). Impact of basamide and methomyl bait on non target pests and some microbiological processes in soil. Egyptpian J. Agric. Res., 83(3): 185-195.

El-Shahaat, M. S., Nagda A. Aly, E. H. Esra, H. A. Mesbah and Emtiaz I. Ghoneim (2009). Toxicity of certain copper fungicides and other pesticides to terrestrialsnails. J. Agric.Sci. Mansoura Univ., 34(5): 5501-5507.

El-Shahaat, M. S., Y. M. Medy and A. S. Merei (1995). Persistence of methonyl baits as mollyscicides and phesiochemical properties of their botanical carriers. Alex. Sci. Exch., 16(2): 185-195.

El-Wakil, H. B. and H. A. Mesbah (1995). Effect of spraying copper sulfate solution on the terrestrial snail Theba pisana (Mull.) and the productivety of Vicia faba (L.). Com. Sci. and Dev. Res., 786(52): 81-88.

Eshra, H. E. (2004). Studies on terrestrial mollusca at some Governorates of West Delta with special reference to its integrated management. PhD. Thesis, Fac. Agric. Al-Azhar Univ., Egypt.

Eshra, E. H. (2013). Survey and distribution of terrestrial snails in fruit orchards and ornamental plants at Alexandria and El-BeheiraGovernorates. Egypt. Alex. Sci. Exchange J., 34: 242-248.

Eshra, E. H. (2014). Toxicity of Methomyl. Copper hydroxide and Urea fertilizer on some Land Snails. Ann. Agric. Sci., 59(2): 281-284.

Eshra, E. H., Y. Abobakr and M. S. El-Shahaat (2015). Seasonal incidence and Chemical Control of Land Snails in Pear Orchards at Alexandria Governorate. J. Adv. Agric. Res. (Fac. Agric. Saba Basha). 20(1): 128-137.

Ghoneim, E. I. E. (2006). Studies on controling the trerestrial mollusca on some horticultural crops. M. Sc. Thesis. Fac. Agric. Saba Basha, Alex. Univ. Egypt, $81 \mathrm{pp}$. 
Godan, D. (1983). Pest slug and snails. biology and control. Springr Verlag Berlin, Hidlberg, pp. 445.

Moran, S., Y. Gotlib and B. Yaakov (2004). Management of land snails in cut green ornamentals by copper hydroxide formulations. J. Crop Prot., 23: 647650.

Ryder, T. A. and I. D. Bowen (1977). The slug food as a baits of uptake of copper molluscicide. J. Invertebr. Pathol., 30: 381-386.

Speiser, B. and C. Kistler (2002). Field test with a molluscicide containg iron phosphate. J. Crop Prot., 21: 389-394.

\section{الملخص العربى \\ تقيم بعض المبيدات الفطرية لمكافحة قوقع الحدائق الأبيض}

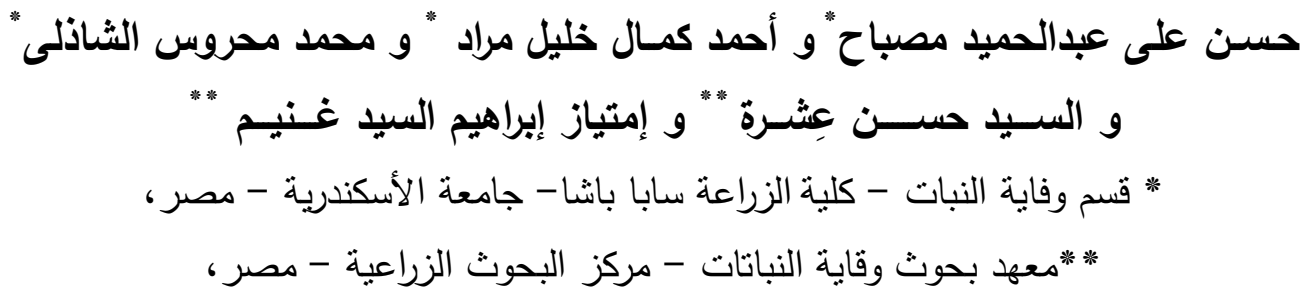

أجريت التجربة أثناء موسم ع ا ب لمكافحة قوقع الحدائق الأبيض تحت الظروف المعطلية باستخدام بعض المبيدات

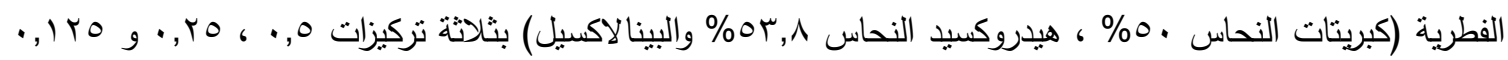

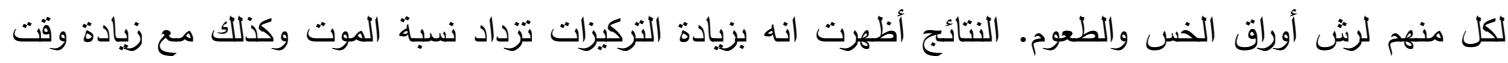

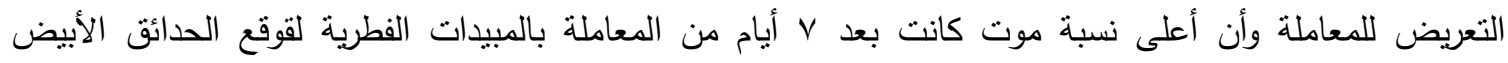

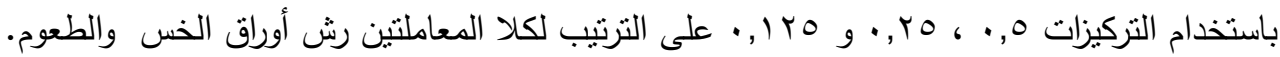

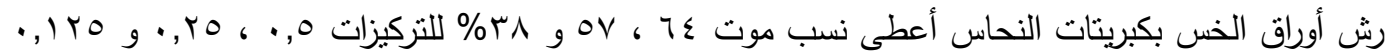

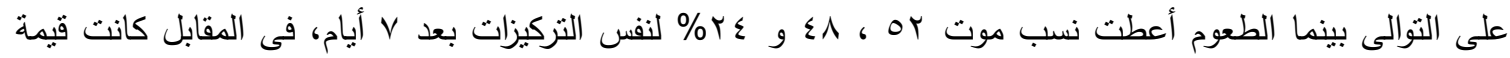

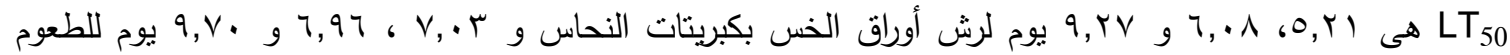

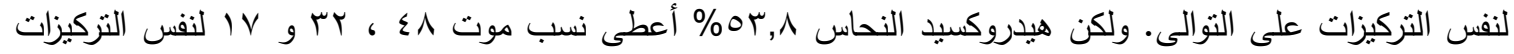

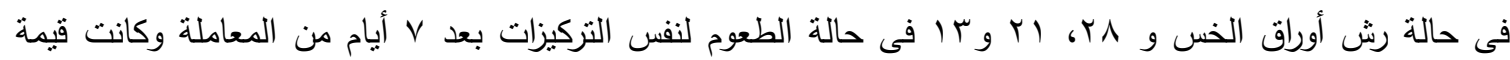

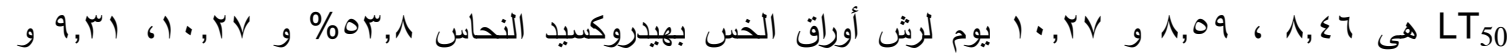

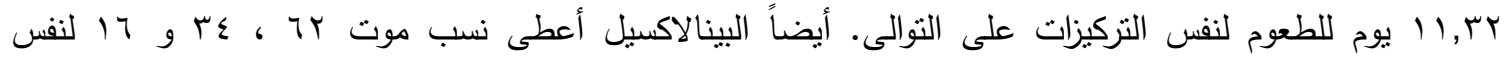

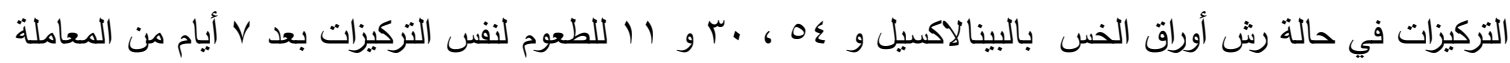

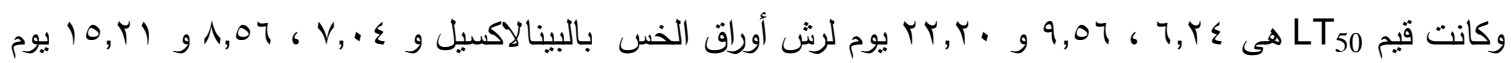
للطعوم عند نفس التزكيزت على الترتيب. 